\title{
Differences in diving and movement patterns of two groups of beluga whales in a changing Arctic environment reveal discrete populations
}

\author{
Frédéric Bailleul ${ }^{1, *}$, Véronique Lesage ${ }^{1}$, Michael Power ${ }^{2}$, David W. Doidge ${ }^{3}$, \\ Mike O. Hammill ${ }^{1}$ \\ ${ }^{1}$ Maurice Lamontagne Institute, 850 route de la Mer, Mont-Joli, Quebec G5H 3Z4, Canada \\ ${ }^{2}$ Department of Biology, University of Waterloo, 200 University Ave. West, Waterloo, Ontario N2L 3G1, Canada \\ ${ }^{3}$ Nunavik Research Center, Makivik Corporation, Kuujjuaq, Quebec J0M 1C0, Canada
}

\begin{abstract}
Harvest and global climate change are among the major ongoing threats to most Arctic marine mammal populations. Affected by commercial hunting in the past, beluga whales Delphinapterus leucas are still harvested for subsistence in many coastal areas of the Canadian Arctic, while ongoing climate changes are suspected to modify factors that may have determined the distribution and degree of interaction of the different populations. Although several populations have been clearly identified, the global discreteness of the Arctic metapopulation is not yet clearly established. In this study, seasonal diving activity and movement patterns of 46 belugas from 2 neighbouring groups in Hudson Bay (Canada) were analysed in relation to physical environmental characteristics and revealed significantly different migratory and habitat use patterns. Likely affected by local environmental conditions, the Eastern Hudson Bay beluga migrate, while the James Bay beluga remain resident, suggesting little overlap between the groups at all times of the year. This study provides useful baseline data for determining population interactions and habitat use. The information is also potentially useful in identifying critical habitat, which is an essential component to design and implement management and conservation policy, e.g. quota and harvesting regulations and the design of marine protected areas.
\end{abstract}

KEY WORDS: Conservation - Arctic changes - Bio-logging - Population mixing - Migration · Delphinapterus leucas · Marine mammals

\section{INTRODUCTION}

Arctic systems are generally characterized by high seasonality in environmental characteristics (e.g. Svendsen et al. 2002). They have also been described as being partially resilient to climate variation because of the amplitude of seasonal fluctuations in environmental conditions, e.g. seasonally varying sea ice cover (Piepenburg 2005). However, the combined rate and magnitude of change expected in the future suggests that Arctic systems will nevertheless be vulnerable to climate change (Walsh 2008). Previous studies have revealed trends over the past 20 to $30 \mathrm{yr}$ of decreasing sea ice extent in the Arctic Ocean coincident with global warming (Maslanik et al. 1996). Such changes are expected to affect polar marine ecosystems (Smetacek \& Nicol 2005).

More specifically, Hudson Bay (Canada) has experienced, and is predicted to further undergo, significant environmental changes that may affect the distribution of marine mammals (Petersen et al. 2010). Within this region, some species may become extirpated or isolated (e.g. southern Hudson Bay polar bears; Stirling et al. 2004), while others may expand 
their ranges (e.g. killer whales) as a result of warmer temperatures (Higdon \& Ferguson 2009). Consequently, the greater Hudson Bay ecosystem may be viewed as an early warning system for the larger Arctic ecosystem. In parallel, the Hudson Bay ecosystem has also been strongly influenced by commercial hunting in the past, which has been responsible for the depletion of many resident marine mammal populations (Reeves 2000). Currently, in many locations within the bay, traditional harvest continues to maintain a negative pressure on especially small and depleted populations.

Beluga whales Delphinapterus leucas have a discontinuous circumpolar distribution in Arctic and sub-Arctic waters (Stewart \& Stewart 1989) and are subdivided into at least 16 provisional management stocks, 11 of which exist in North America. Four of these stocks are currently recognized for management purposes in the Canadian Eastern Arctic (Donovan 1992). It is generally assumed that groups of belugas associated with particular summering areas constitute separate stocks (e.g. Reeves \& Mitchell 1987), and to date, genetic studies have not disproven this postulate (Buchanan et al. 1996). The species undertakes seasonal migrations of varying extents, ranging from several hundreds of kilometres in the Beaufort Sea (Richard et al. 2001), to tens of kilometres in the St. Lawrence estuary (Lesage \& Kingsley 1998). In other areas, e.g. Cook Inlet and Cumberland Sound, beluga populations reside in the same locale all year round (Moore et al. 2000). Although the variability among populations in the extent of seasonal movement is thought to be related to food availability and risks of ice entrapment or predation, the relative importance of these environmental factors in shaping population-specific habitat use and migration patterns is unknown. In a warming climate, a reduction in sea ice coverage might affect prey availability and entrapment risks, causing changes to existing population-specific migratory patterns (Walther et al. 2002). Therefore, climate change may lead to significant modifications in the geographic range and distribution of belugas and the degree of overlap among stocks.

Belugas in Hudson Bay are divided into a western population that may encompass more than 1 stock, and an eastern population centred on the Hudson Bay arc (hereafter referred to as EHB; Brennin et al. 1997). The western population is currently designated as being of special concern (COSEWIC 2004), while the eastern population, which declined from 4200 to 3100 individuals over the period 1985 to 2004 (Doniol-Valcroze et al. 2011), is designated as endan- gered (COSEWIC 2004). Both populations undertake seasonal migrations through Hudson Strait, where their distribution likely overlaps (DeMarch \& Postma 2003). Other congregations of belugas reported in areas in and adjacent to Hudson Bay include the Foxe Basin, south-western Hudson Bay, Belcher Islands and James Bay (Richard et al. 1990). The relationship of these stocks to the western and EHB stocks and their patterns of seasonal movement remain unclear.

Remote sensing and satellite telemetry have proven to be powerful tools for obtaining data on the seasonal movement patterns and habitat characteristics of wildlife, especially for large marine species, e.g. belugas, that would otherwise be difficult to observe in situ (Ropert-Coudert \& Wilson 2005). Coupled with knowledge of environmental correlates now routinely available from satellites, telemetry data may enhance our understanding of the environmental factors that lead to seasonal migrations. In the present study, we have synthesized information on seasonal diving activity, movement patterns and associated environmental factors for belugas from 2 neighbouring geographical regions of the Hudson Bay complex in northern Canada, to investigate patterns of seasonal habitat use in relation to the physical environment available to belugas. In particular, we attempt to provide evidence of stock discreteness and to identify physical environmental features of beluga habitat that may help improve our ability to design and implement proactive conservation and management policies aimed at sustaining beluga populations confronted with combined harvest and environmental stressors.

\section{MATERIALS AND METHODS}

\section{Characteristics of devices}

Different satellite transmitters were used: SPOT tags (location and temperature recorders), SDR-T16 tags (satellite-linked time-depth recorders), both from Wildlife Computers, or temperature depthsatellite relayed data loggers (TD-SRDLs) from the Sea Mammal Research Unit (SMRU; St. Andrews, UK). TD-SRDLs were microprocessor-controlled recording units equipped with a pressure transducer (pressure \pm 2 dbar), temperature probe (temperature $\pm 0.005^{\circ} \mathrm{C}$ ) and real-time internal clock. All sensors were contained in a $105 \times 70 \times 40 \mathrm{~mm}$ resin housing weighing about $500 \mathrm{~g}$ and operational to depths of $2000 \mathrm{~m}$. Data from SPOT and SDR-T16 tags were 
processed using the SATPAK and SATPAK2003 applications provided by Wildlife Computers, while data from TD-SRDLs were processed automatically by the SMRU applications and were made available in a standardized database format.

\section{Whale capture and attachment of devices}

From 1993 to 2009, 51 belugas were captured using 6 inch $(\sim 15 \mathrm{~cm})$ square mesh, shore-anchored nets, and equipped with tags secured to the dorsal ridge (Richard et al. 1997, Kingsley et al. 2001). Thirtyseven animals (12 females, 18 males and 7 of unknown sex) were tagged in July or August between 1993 and 2004 in the EHB arc (32 at the Little Whale River and 5 at the Nastapoka River). From 2007 to 2009, an additional 14 (11 females and 3 males) were captured and equipped at Cape Hope Island, James Bay (JB). Five EHB belugas (hereafter referred to as EHBB) with less than $15 \mathrm{~d}$ of data were removed from the analyses, resulting in final sample of $32 \mathrm{EHBB}(11$ females, 17 males and 4 undetermined) and 14 belugas from JB (hereafter referred to as JBB; Table 1).

\section{Location data}

Locations were obtained via the ARGOS satellite system. Locations were classified according to their estimated accuracy: 250, 500, 1500 and $>1500 \mathrm{~m}$ for classes 3 through 0 (Argos). Classes A, B and Z had undetermined accuracies. Unrealistic locations were rejected using a forward particle-filtering model (Tremblay et al. 2009). The model assumes that each location corresponds to the geographic average of the many possible positions, the spread of which is a function of location accuracy. The first step of the filtering procedure consists of generating a number, here 50, of random locations (or 'particles') inside a circle around each recorded position, of a radius that depends on its estimated accuracy. Each particle is weighted according to the likelihood of the speed needed to get there from the previous recorded location. A maximum speed of $3 \mathrm{~m} \mathrm{~s}^{-1}$ was considered, based on the assumption that belugas rarely travel at speeds faster than this (e.g. Richard et al. 1998). Information on local ocean depth (source: ETOPO 1, see 'Environmental features') is used to eliminate particles that are on land. At each step, a new particle is randomly selected and used to create the next position. The output of this method is $\mathrm{n}$ complete tracks, each corresponding to 1 boot-strapped track iteration (here n: 50). The 'best track' can then be computed as the geographic average of the bootstrapped tracks (Tremblay et al. 2009).

\section{Diving behaviour}

Belugas were considered to be diving when recorded depth exceeded $4 \mathrm{~m}$, otherwise they were defined to be at the surface. A summary record, including proportion of time spent diving or at the surface, number of dives, and mean, maximum and standard deviation (SD) of maximum dive depth and duration, was compiled for each $6 \mathrm{~h}$ period for each track. Compilation was processed directly by the SMRU and included in the database for the 24 SMRU tags, while we developed an $\mathrm{R}$ program for the 22 Wildlife Computer tags.

For each dive, we extracted the local ocean depth (source: ETOPO 1, see 'Environmental features'). The ratio between the maximum dive depth and local ocean depth was used as an index of the position of the individual in the water column, with an index closed to 1 indicating a demersal activity.

\section{Environmental features}

Satellite remote sensing data were also used to complement the set of oceanographic data collected by the animals. Ocean depth was obtained from ETOPO1 (NOAA National Geophysical Data Center, http://ngdc.noaa.gov/mgg/global/global.html), a 1 arc-minute global relief model of the Earth's surface that integrates land topography and ocean bathymetry. Data on sea surface temperature (SST, $4 \times 4 \mathrm{~km}$ resolution) used in the discussion and presented in Fig. 6 were gathered using the PO.DAAC Ocean ESIP Tool (POET, http://poet.jpl.nasa.gov/), while data for sea ice concentration $\left(1^{\circ} \times 1^{\circ}\right)$ were collected via the Integrated Global Ocean Services System (IGOSS, http://iridl.ldeo.columbia.edu/).

\section{Analyses of residency versus migration patterns}

Seasons were defined using the traditional calendar for the northern hemisphere: summer from 21 June to 22 September, fall from 23 September to 21 December and winter from 22 December to 20 March. Spring was not considered in this study because all tags had failed by the end of March and, as a consequence, no data were available for that 
Table 1. Delphinapterus leucas. Synthesis of deployments. Belugas were captured in 2 different locations, EHB: Eastern Hudson Bay and JB: James Bay. Colour of individuals is an index of their age from younger (G: gray, LG: light gray) to older (W: white) animals. Total number of locations is only indicated for the individuals included in the analyses. ?: unknown

\begin{tabular}{|c|c|c|c|c|c|c|c|c|c|}
\hline ID_year & $\begin{array}{l}\text { Tag } \\
\text { type }\end{array}$ & $\begin{array}{c}\text { Site of } \\
\text { capture }\end{array}$ & Sex & $\begin{array}{l}\text { Length } \\
\text { (cm) }\end{array}$ & Colour & $\begin{array}{c}\text { Deployment } \\
\text { date (dd/mm) }\end{array}$ & $\begin{array}{c}\text { Total } \\
\text { locations }\end{array}$ & $\begin{array}{c}\text { Record } \\
\text { duration (d) }\end{array}$ & $\begin{array}{c}\text { Total } \\
\text { distance }(\mathrm{km})\end{array}$ \\
\hline 11747_1993 & SDR-T16 & EHB & $?$ & 280 & $\mathrm{G}$ & $12 / 08$ & - & 30 & 1472 \\
\hline 11748_1993 & SDR-T16 & EHB & $?$ & $?$ & W & $15 / 08$ & - & 19 & 592 \\
\hline 5090_1993 & SDR-T16 & EHB & $?$ & 390 & $\mathrm{~W}$ & $12 / 08$ & - & 43 & 1855 \\
\hline 17908_1999 & SDR-T16 & EHB & $?$ & 270 & G & $29 / 07$ & - & 39 & 1639 \\
\hline 1854_1999 & SDR-T16 & EHB & $\mathrm{F}$ & 310 & W & $29 / 07$ & - & 85 & 3976 \\
\hline 2014_1999 & SDR-T16 & EHB & $\mathrm{F}$ & 330 & G & $29 / 07$ & - & 25 & 304 \\
\hline 17905_2002 & SPOT & EHB & M & 375 & W & $28 / 07$ & 307 & 122 & 5479 \\
\hline 17906_2002 & SPOT & EHB & M & 394 & $\mathrm{~W}$ & $28 / 07$ & 325 & 136 & 4954 \\
\hline 17911_2002 & SPOT & EHB & M & 290 & LG & $24 / 07$ & - & 69 & 2374 \\
\hline 1851_2002 & SDR-T16 & EHB & $\mathrm{F}$ & 342 & $\mathrm{~W}$ & $20 / 07$ & - & 80 & 4131 \\
\hline 1852_2002 & SDR-T16 & EHB & $\mathrm{F}$ & 332 & W & $24 / 07$ & 1389 & 165 & 10858 \\
\hline 1853_2002 & SDR-T16 & EHB & $\mathrm{M}$ & 353 & LG & $19 / 07$ & - & 44 & 2396 \\
\hline 1855_2002 & SDR-T16 & EHB & M & 321 & $\mathrm{~W}$ & $24 / 07$ & 1667 & 175 & 10553 \\
\hline 17905_2003 & SDR-T16 & EHB & M & 294 & G & $22 / 07$ & 1380 & 149 & 8818 \\
\hline 17906_2003 & SDR-T16 & EHB & M & 315 & G/W & $23 / 07$ & 1229 & 153 & 9155 \\
\hline 17911_2003 & SDR-T16 & EHB & M & 360 & W & $27 / 07$ & 1547 & 222 & 10538 \\
\hline 1851_2003 & SPOT & EHB & $\mathrm{F}$ & 230 & G & $22 / 07$ & - & 48 & 1492 \\
\hline 1852_2003 & SPOT & EHB & M & 265 & G & $11 / 07$ & 999 & 200 & 8449 \\
\hline 1853_2003 & SPOT & EHB & M & 310 & $\mathrm{G}$ & $14 / 07$ & 627 & 214 & 7644 \\
\hline 1854_2003 & SPOT & EHB & M & 295 & $\mathrm{G}$ & $27 / 07$ & 711 & 266 & 10252 \\
\hline 1855_2003 & SPOT & $\mathrm{EHB}$ & $\mathrm{M}$ & 325 & $\mathrm{G}$ & $27 / 07$ & - & 56 & 1515 \\
\hline $3022 \_2003$ & SMRU & EHB & $\mathrm{M}$ & 385 & W & $11 / 07$ & 2711 & 220 & 14669 \\
\hline 3415_2003 & SMRU & EHB & $\mathrm{F}$ & 335 & W & $22 / 07$ & 3988 & 209 & 14057 \\
\hline 5091_2003 & SDR-T16 & EHB & $\mathrm{F}$ & 335 & W & $22 / 07$ & - & 46 & 2184 \\
\hline 9365_2004 & SMRU & EHB & M & 300 & LG & $09 / 07$ & - & 71 & 4675 \\
\hline 9366_2004 & SMRU & $\mathrm{EHB}$ & $\mathrm{F}$ & 350 & $\mathrm{~W}$ & $04 / 07$ & - & 105 & 4326 \\
\hline 9367_2004 & SMRU & EHB & $\mathrm{F}$ & 361 & $\mathrm{~W}$ & $18 / 07$ & 2019 & 272 & 17433 \\
\hline 9371_2004 & SMRU & EHB & M & 281 & G/W & $14 / 07$ & - & 95 & 6688 \\
\hline 9378_2004 & SMRU & EHB & M & 310 & $\mathrm{G} / \mathrm{W}$ & $04 / 07$ & 768 & 187 & 9790 \\
\hline 9379_2004 & SMRU & EHB & $\mathrm{F}$ & 348 & W & $12 / 07$ & 1073 & 156 & 8903 \\
\hline 9390_2004 & SMRU & EHB & M & 370 & W & $17 / 07$ & 2511 & 292 & 20407 \\
\hline 9392_2004 & SMRU & EHB & $\mathrm{F}$ & 350 & $\mathrm{~W}$ & $21 / 07$ & 824 & 112 & 7664 \\
\hline 44436_2007 & SMRU & $\mathrm{JB}$ & $\mathrm{F}$ & 304 & $\mathrm{~W}$ & $14 / 08$ & 696 & 83 & 2898 \\
\hline 44485_2007 & SMRU & JB & M & 299 & LG & $20 / 08$ & 558 & 84 & 3224 \\
\hline 44436_2008 & SMRU & JB & $\mathrm{F}$ & 341 & $\mathrm{~W}$ & $16 / 08$ & 978 & 149 & 4500 \\
\hline 44446_2008 & SMRU & JB & $\mathrm{F}$ & 353 & $\mathrm{~W}$ & 06/08 & 219 & 115 & 694 \\
\hline 44447_2008 & SMRU & JB & $\mathrm{F}$ & 275 & LG & 08/08 & 1132 & 137 & 6465 \\
\hline 44451_2008 & SMRU & JB & $\mathrm{F}$ & 331 & $\mathrm{~W}$ & 08/08 & 742 & 115 & 4337 \\
\hline 44452_2008 & SMRU & JB & $\mathrm{F}$ & 333 & $\mathrm{~W}$ & $10 / 08$ & 293 & 47 & 2220 \\
\hline 44477_2008 & SMRU & JB & $\mathrm{F}$ & 310 & W & $16 / 08$ & 1035 & 210 & 6596 \\
\hline 44478_2009 & SMRU & JB & $\mathrm{M}$ & 289 & W & $09 / 08$ & 924 & 117 & 3354 \\
\hline 44479_2009 & SMRU & JB & $\mathrm{F}$ & 366 & W & $30 / 07$ & 2123 & 156 & 8283 \\
\hline 44480_2009 & SMRU & JB & $\mathrm{F}$ & 344 & W & $31 / 07$ & 1782 & 176 & 9081 \\
\hline 44481_2009 & SMRU & JB & $\mathrm{F}$ & 288 & LG & $10 / 08$ & 737 & 156 & 4761 \\
\hline 44482_2009 & SMRU & JB & $\mathrm{F}$ & 310 & LG & $02 / 08$ & 1496 & 193 & 8707 \\
\hline 44483_2009 & SMRU & $\mathrm{JB}$ & $\mathrm{F}$ & 306 & LG & 01/08 & 299 & 58 & 1579 \\
\hline
\end{tabular}

period. Areas of residency were identified using a first-passage time approach (FPT) as described by Fauchald \& Tveraa (2003). The method was applied to the entire filtered track of each individual, which was fragmented and interpolated to obtain 1 location every $2 \mathrm{~km}$. Each location was associated with a circle of a fixed radius $r$. The time required for crossing the circle in the first passage (i.e. the FPT value) was calculated. The computational process was repeated for each location and for a range of $r$ (here from 2 to $800 \mathrm{~km}$ ). Over the entire track, the variance among the FPT values (log-transformed: see Fauchald \& Tveraa 2003) was calculated as a function of $r$. The radius corresponding to the maxi- 
mum peak in variance indicated the most relevant scale to differentiate the highest FPT values that revealed residency patterns from the lowest ones that revealed migration patterns. To spatially locate where an animal was resident and the time spent in that area, FPT values associated with the most relevant scale were plotted as a function of time since departure. The areas where tracks tended to be tortuous and movements repetitive yielded the highest FPT values and were defined as 'residency' areas (Fauchald \& Tveraa 2003). In contrast, the lowest FPT values, especially those located between the end of summer and the beginning of fall, defined the fall migration period. The date of shift between high and low FPT states was defined as the date of departure for migration and validated by determining whether a route outside the residency area without return existed.

\section{RESULTS}

\section{Seasonal movements}

Of the 46 belugas with data records for $\geq 15 d, 29$ individuals, including 17 EHBB and 12 JBB (all tagged in 2002 or later), had records that extended beyond the summer season (Table 1). Belugas from these 2 neighbouring regions differed markedly in their seasonal movements. The 17 EHBB still transmitting in the winter had migrated out of Hudson Bay by mid-November, while all $12 \mathrm{JBB}$ still transmitting on that date were still in JB and remained there until their last day of transmission (mid-November to mid-March; Fig. 1).

The analysis of FPT identified 3 seasonally-dependent residency areas for $\mathrm{EHBB}$, i.e. EHB, Ungava Bay (UB) and the Labrador Sea (LS; Fig. 1). The mean scale of restricted search decreased from $158 \pm 61 \mathrm{~km}$

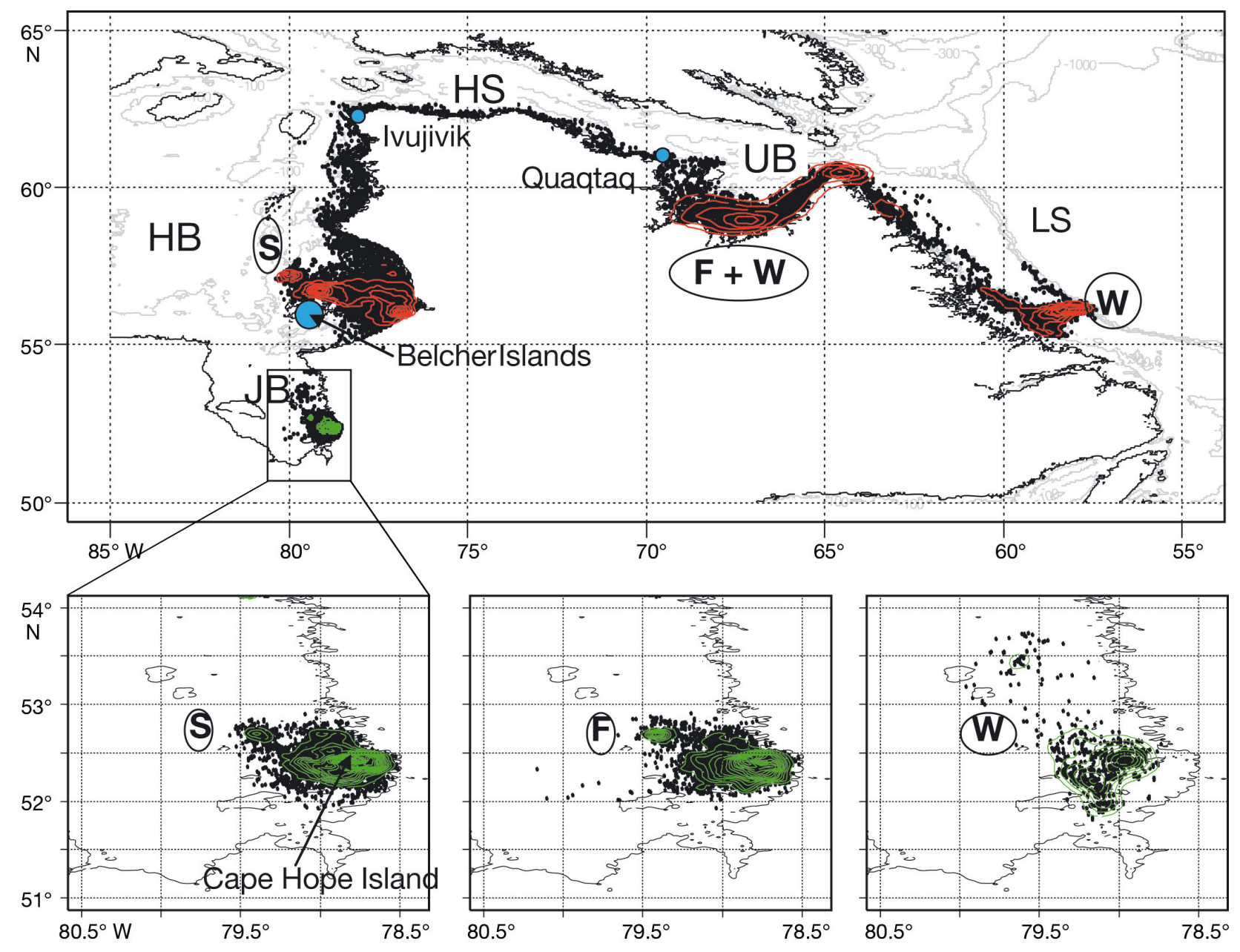

Fig. 1. Delphinapterus leucas. Hudson Bay beluga complex showing all locations recorded during the study (black dots). Density curves $(95 \%)$ in red indicate the main residency areas of eastern Hudson Bay (HB) belugas in summer (S), fall (F) and winter (W). Density curves (95\%) in green indicate the same for belugas in James Bay (JB). HS: Hudson Strait, UB: Ungava Bay, 
in the summering area $(\mathrm{EHB})$ to $104 \pm 65 \mathrm{~km}$ in UB and $67 \pm 68 \mathrm{~km}$ in the wintering area (LS; Table 2). At the beginning of summer, tracks of EHBB indicated regular inshore-offshore movements of an average $119 \pm 74 \mathrm{~km}$ (max: $425 \mathrm{~km}$ ) from their tagging site. Although all animals immediately left the capture site after being tagged, 28 individuals (i.e. 87.5\%) returned to it at least once during the summer. The first time was on average less than $10 \mathrm{~d}$ after capture. Starting in September, all individuals moved offshore, with 23 belugas (i.e. $72 \%$ ) moving closer to the northern coast of the Belcher Islands (Fig. 1).

The shift from high to low FPT values indicated a departure from EHB between 19 September and 26 November, depending on the individual (mean $\pm \mathrm{SD}$ : 16 October $\pm 18 \mathrm{~d}$ ). Animals moved to the Hudson Strait and Ivujivik area, approximately $400 \mathrm{~km}$ north of the EHB arc, and reached the strait on average 10 $\pm 12 \mathrm{~d}$ after departure. During the migration phase,

Table 2. Delphinapterus leucas. Spatial scale of restricted movement of Eastern Hudson Bay (EHB) and James Bay (JB) belugas within their summer, fall and winter residency areas as determined by the first-passage time (FPT) analysis. -: no scale was identified

\begin{tabular}{|c|c|c|c|c|}
\hline \multirow[t]{2}{*}{ ID_year } & \multirow{2}{*}{$\begin{array}{c}\text { Site of } \\
\text { capture }\end{array}$} & \multicolumn{3}{|c|}{ Scale of restricted movement $(\mathrm{km})$} \\
\hline & & Summer & Fall & Winter \\
\hline 17905_2002 & EHB & 190 & 240 & 50 \\
\hline 17906_2002 & EHB & 200 & 100 & 25 \\
\hline 1852_2002 & EHB & 170 & 110 & - \\
\hline 1855_2002 & EHB & 85 & 25 & - \\
\hline 17905_2003 & EHB & - & 90 & 15 \\
\hline 17906_2003 & EHB & 200 & 85 & 20 \\
\hline 17911_2003 & EHB & 170 & 55 & - \\
\hline 1852_-̄o03 & EHB & 55 & 110 & - \\
\hline 1853_2003 & EHB & 120 & 90 & 100 \\
\hline 1854_2003 & EHB & 65 & 220 & - \\
\hline 3022_2003 & EHB & 200 & 220 & 20 \\
\hline 3415_2003 & EHB & 280 & 45 & 35 \\
\hline $9367-2004$ & EHB & 140 & 70 & - \\
\hline 9378_2004 & EHB & 110 & 90 & - \\
\hline 9379_2004 & EHB & 190 & 70 & 220 \\
\hline 9390_2004 & EHB & 220 & - & 120 \\
\hline 9392_2004 & EHB & 140 & 50 & - \\
\hline 44436_2007 & JB & 20 & 10 & - \\
\hline 44485_2007 & JB & 25 & 15 & - \\
\hline 44436_2008 & JB & 25 & 15 & - \\
\hline 44446_2008 & JB & - & - & - \\
\hline 44447_2008 & JB & 35 & 20 & - \\
\hline 44451_2008 & JB & - & 10 & - \\
\hline 44477_2008 & JB & 25 & 35 & - \\
\hline 44478_2009 & JB & 10 & 6 & - \\
\hline 44479_2009 & JB & 25 & 40 & - \\
\hline 44480_2009 & JB & 8 & 30 & 20 \\
\hline 44481_2009 & JB & 40 & 20 & 20 \\
\hline 44482_2009 & JB & 25 & 20 & - \\
\hline
\end{tabular}

animals remained $15 \pm 12 \mathrm{~km}$ from shore (range: 0.05 to $61.5 \mathrm{~km}$ ). EHBB continued eastward through Hudson Strait towards Quartaq and the UB, while remaining within $14 \pm 11 \mathrm{~km}$ (range: 0.57 to $50 \mathrm{~km}$ ) from shore (Fig. 1). On average, it took animals $7 \pm 4 \mathrm{~d}$ to cover the $500 \mathrm{~km}$ distance separating Ivujivik and Quartaq at the entrance of UB, resulting in a mean total migration time of $22 \pm 9 \mathrm{~d}$ and a mean swimming speed of $2.0 \pm 0.6 \mathrm{~km} \mathrm{~h}^{-1}$.

The 17 EHBB then entered UB, where they spent time in the southeastern part of the bay (Fig. 1). Tags from 8 whales failed after spending $44 \pm 28 \mathrm{~d}$ there (range: 12 to $107 \mathrm{~d}$ ). The last transmission from a tag in this area was in late February, indicating that at least 1 individual spent a substantial portion of the winter in the bay. The other 9 individuals left UB between 1 and 25 December, after spending on average $40 \pm 17 \mathrm{~d}$ there (range: 6 to $55 \mathrm{~d}$ ). EHBB then migrated approximately $570 \mathrm{~km}$ along the coast to an area of deep troughs along the Labrador shelf in the LS, where they arrived between 31 December and 23 January and remained until tag failure $61 \pm 46$ d later (Fig. 1). All transmitters had ceased functioning by 5 March.

In contrast with EHBB, JBB had a distribution which varied seasonally little. All animals remained within JB as long as the tags transmitted (mean \pm SD: $144 \pm 68$ d, median: 140 d, range: 45 to $299 \mathrm{~d}$ ). With the exception of 3 individuals that moved to the northern part of the bay in January, JBB generally did not venture far from their tagging site (Cape Hope Island) where they returned regularly until tag failure (5 November to 10 February; Fig. 1). The mean scale of restricted search in JB did not vary seasonally (summer: $23.8 \pm 9.7 \mathrm{~km}$; fall: $20.1 \pm 10.8 \mathrm{~km}$, $t_{18.99}=0.83, \mathrm{p}=0.42$; small sample size for winter prevented inclusion in the analysis; Table 2).

\section{Diving activity}

In EHB, diving activity markedly increased when belugas were located to the north of the Belcher Islands and was maintained at a maximum, around $80 \%$ of total time, for the 1 to 2 mo preceding the fall migration (Fig. 2a). While the EHBB used the entire water column when close to the mainland coast, most dives in the vicinity of the Belcher Islands were closer to the sea floor (Fig. 3a). With the onset of migration, diving activity decreased compared to the end of summer, although it still represented between 60 and $70 \%$ of their time (Fig. 2a). Diving activity increased again to about $80 \%$ of total time when animals reached the UB fall residency area (Fig. 2a), although 

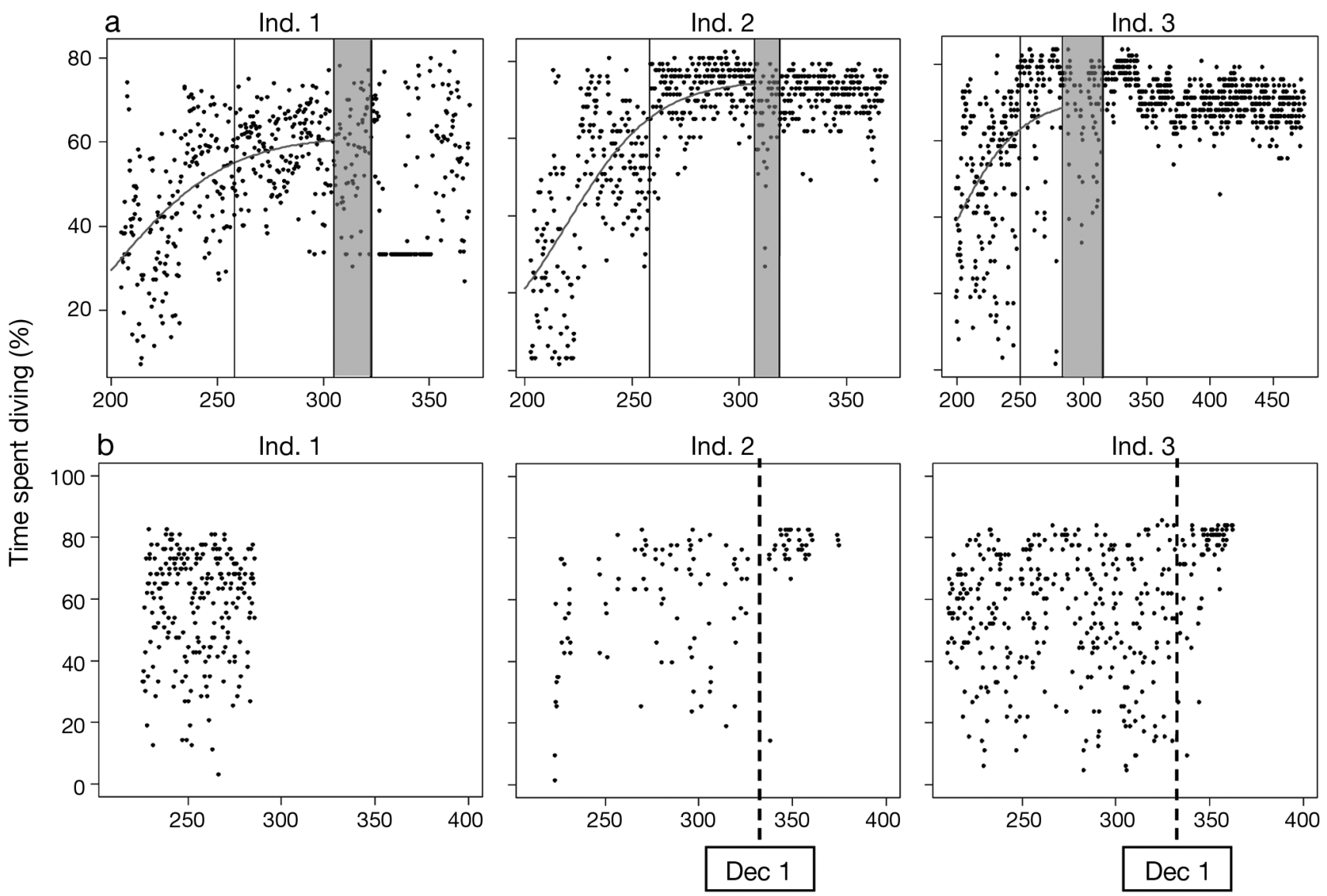

Date (d)

Fig. 2. Proportion of time spent diving according to date for (a) 3 individuals from Eastern Hudson Bay (EHB) that showed a progressive increase in diving activity to reach a maximum in September, about 1 or 2 mo before migration (in gray) (as illustrated by the curve), and (b) 3 individuals from James Bay (JB) that showed an increase in diving activity only from December

no specific depth seemed to be preferred during their stay in this area (Fig. 3b). Belugas wintering in the LS continued to spend a large proportion (80\%) of their time diving (Fig. 2a). There, individuals either remained close to the surface or dived close to the sea floor, spending little time in between (Fig. 3c).

In JB, diving activity was highly variable until December (Fig. 2b), when it increased substantially and was maintained at a high level (around $80 \%$ of time) until the tags failed (Fig. 2b). Although JBB tended to use the entire water column (Fig. 3d), they dived significantly deeper during winter (from December; $29 \pm$ $18 \mathrm{~m})$ than during summer and fall $(16 \pm 13 \mathrm{~m} ; t=$ $37.4, \mathrm{p}<0.001)$.

\section{Environmental correlates}

EHBB preferentially used relatively shallow waters (58 $\pm 28 \mathrm{~m}$; Fig. 4). The habitat was characterized by strong thermal stratification of the water column (range: -1.5 to $13.5^{\circ} \mathrm{C}$ ), with a thermocline located at around $40 \mathrm{~m}$. EHBB dived mainly around the thermocline during summer (Fig. 5a). Diving activity increased in September, when belugas occupied areas to the north of the Belcher Islands where the water column was more homogeneous in temperature, at around $3^{\circ} \mathrm{C}$ (Fig. 5a). In UB, EHBB generally used deeper waters $(119 \pm 84 \mathrm{~m})$. Although there were clear indications from some tracking positions that individuals entered river estuaries in UB, no particular depth was favoured (Fig. 4) within the well-mixed water column $\left(\approx 1^{\circ} \mathrm{C}\right)$. In the LS, EHBB preferentially selected an area on the continental plateau characterized by a deep trough (353 $\pm 171 \mathrm{~m}$; Fig. 4). In this region, most of the water column had temperatures of $\approx 0^{\circ} \mathrm{C}$, with a minimum of $-1.8^{\circ} \mathrm{C}$. The one exception was a deep zone where EHBB systematically dove to depths where temperatures were between 3 and $4{ }^{\circ} \mathrm{C}$. 

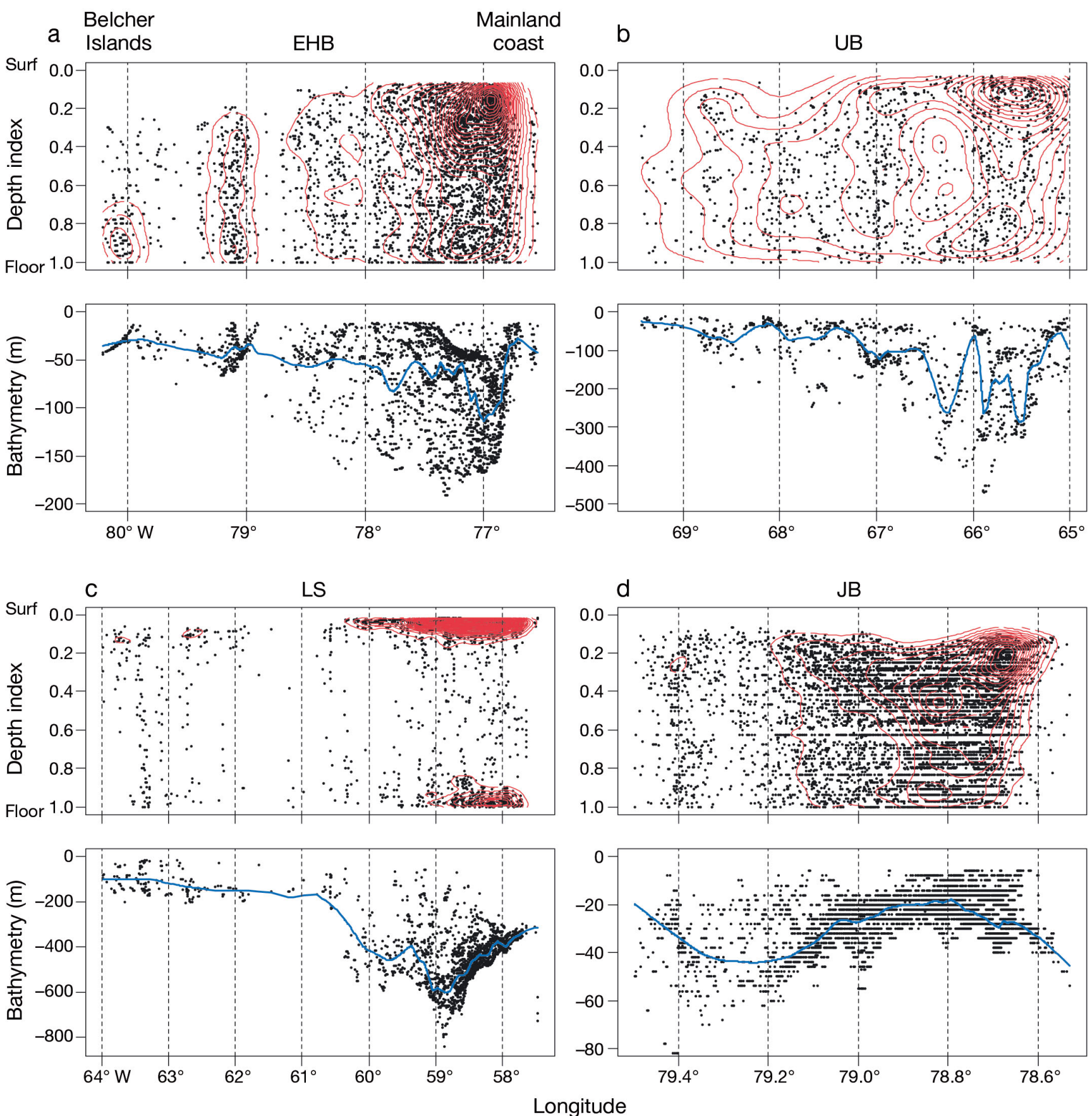

Fig. 3. Delphinapterus leucas. Density (red curves, external curve $=95 \%$ ) of diving activity through the water column. Depth index is the ratio between maximum dive depth and corresponding bathymetry: 0 corresponds to the sea surface (surf), and proximity to the sea floor increases as the index approaches 1. Bathymetry corresponding to each dive is also shown, and a smooth curve (in blue) shows the relative shape of the sea floor. (a) Eastern Hudson Bay, EHB; (b) Ungava Bay, UB; (c) Labrador Sea, LS; (d) James Bay, JB

The habitat preferentially used by JBB was shallow $(25 \pm 10 \mathrm{~m})$ and generally warm, with a strong thermal stratification (range: 2.5 to $15^{\circ} \mathrm{C}$ ) during summer (Fig. 5b). Starting in October, water temperatures began to homogenize and progressively decreased to reach negative values in December (range: -1.3 to $3.6^{\circ} \mathrm{C}_{i}$ Fig. $5 \mathrm{~b}$ ). An intensification of JBB diving activity was observed at this time (Fig. 5b). 

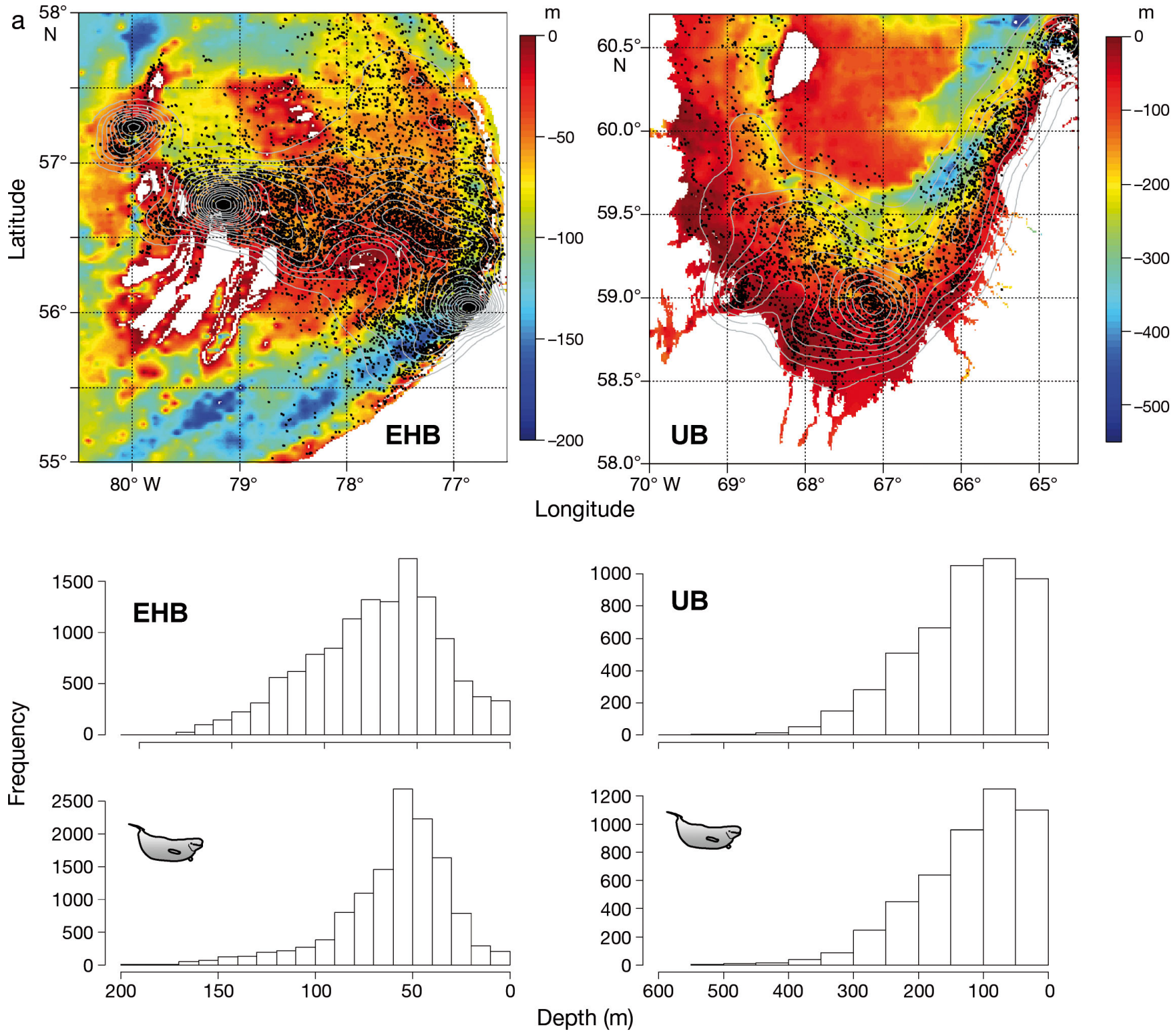

Fig. 4 (continued over page). Delphinapterus leucas. Bathymetry in each residency area associated with position (black dots) of all individuals (density curves in gray, external curve $=95 \%$ ). Histograms represent values of bathymetry extracted under random locations (top graphs) in each area in comparison with values extracted using known beluga positions (bottom graphs); $\mathrm{n}=$ number of beluga positions. (a) Eastern Hudson Bay, EHB, and Ungava Bay, UB; (b) (next page) Labrador Sea, LS, and James Bay, JB

\section{DISCUSSION}

The analysis of seasonal diving activity, movements and associated measures of the physical environment for 2 neighbouring groups of belugas from the Hudson Bay complex revealed significant between- and within-population differences in movement patterns and diving activity. Movement patterns within JB were limited to a few tens of kilometres regardless of season, and there is a strong probability that JBB reside year round in the bay. However, this cannot be confirmed because of loss of tags over time. In contrast, EHBB migrate thousands of kilometres between distinct summer and winter residency areas. Although the tagged individuals in our study may not demonstrate the complete range of variation in movements for the 2 groups, the consistency in movement patterns and habitat use among individuals from the same region suggests that our samples were statistically 

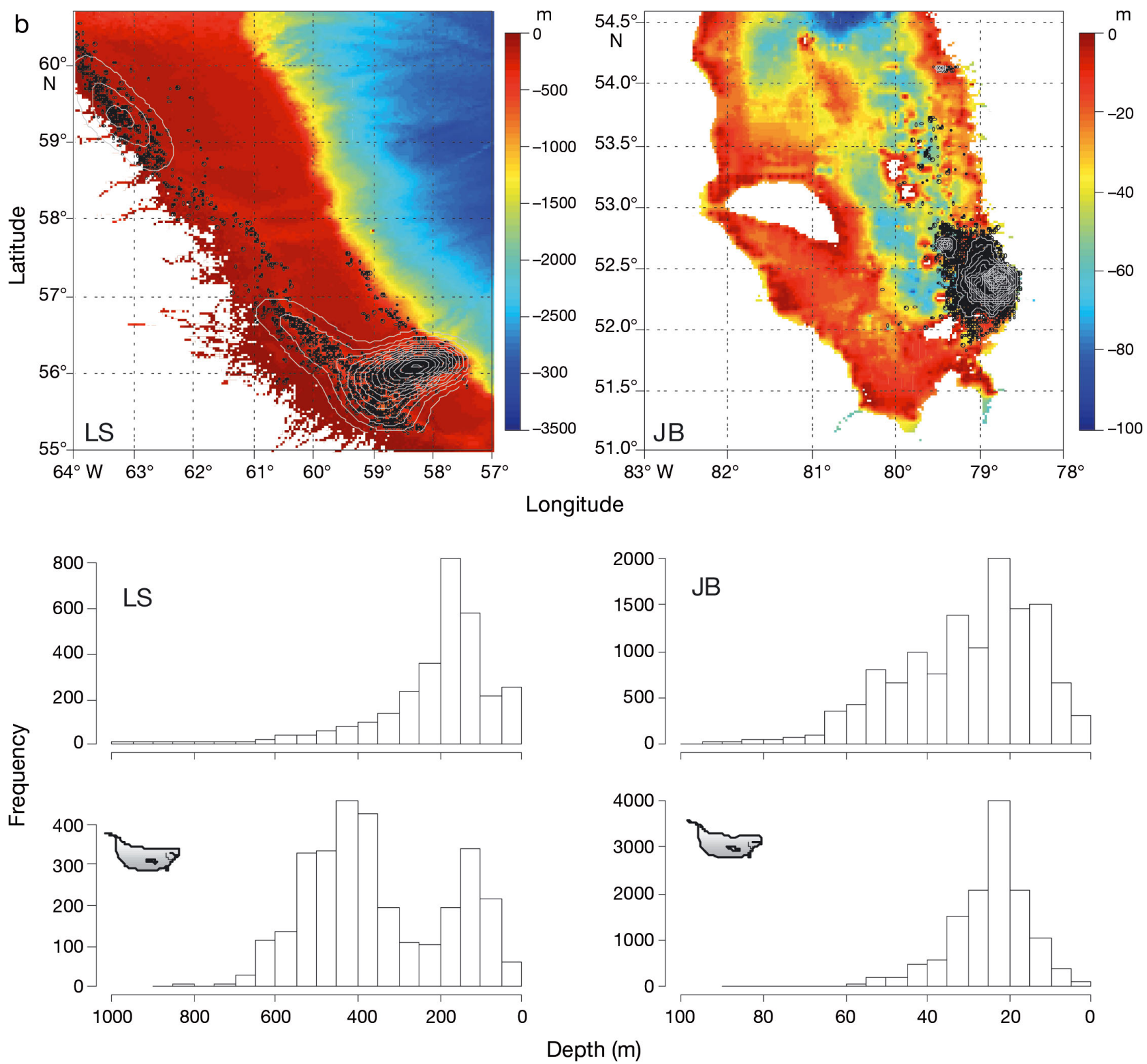

Fig. 4. (continued)

representative of the 2 populations. Although tag battery life was insufficient to document the spring migration, reports from Inuit hunters suggest a westward movement of beluga back into EHB along the south coast of Hudson Strait from late May through July (Lewis et al. 2009). These reports, when combined with previous studies documenting re-sightings of individuals identifiable by scars in the same estuary over successive years, suggest a certain degree of site fidelity, at least in EHBB (Caron \& Smith 1990).

\section{Belugas from Eastern Hudson Bay}

During summer, belugas from several populations are known to consistently congregate in shallow coastal waters or river estuaries. The life-history functions of these areas are unknown and may vary among sites, but might include thermal advantages for females and calves, feeding, moulting and predator avoidance (St. Aubin et al. 1990, Watts et al. 1991, Boily 1995, Richard et al. 2001). Arctic estuaries, in particular, are known to have some of the world's 
highest concentrations of dissolved organic matter (DOM) and, thus, to be highly productive (Hessen et al. 2010). In EHB, where belugas undertake frequent inshore (estuaries) to offshore movements, the movements may represent multiple foraging trips influenced by the cyclicity of tidally-driven prey accessibility (Ezer et al. 2008).

Starting in September, animals stopped the inshore-offshore pattern of movements and most moved to a small area to the north of the Belcher Islands where they increased the frequency of demersal diving activity. Aggregations of marine mammals and seabirds are often associated with abundant prey resources constituted by fish schools (Welch et al. 1993). EHBB probably have, as many other belugas populations do, a diverse diet (e.g. Hobbs et al. 2008). Although their diet has not been well described, it is likely to include both capelin Mallotus villosus and Arctic cod Boreogadus saida, which are important components of Arctic marine food webs and form dense aggregations during the open-water season (Welch et al. 1993, Kelley et al. 2010). Accordingly, belugas may be congregating north of the Belcher Islands to exploit aggregations of these, or other, prey species.

During their seasonal migration, EHBB remained close to the coastline, a migration strategy that may allow them to benefit from the northwardflowing current that prevails along the east side of Hudson Bay (Saucier et al. 2004). Along the Labrador coast, beluga diving activity suggests repeated movement between partially ice-covered sea surface habitats and warmer, deep-sea areas. Such activity may be associated with foraging.

\section{Belugas from James Bay}

JBB displayed markedly different seasonal movements and habitat use characteristics from EHBB, which suggests that they likely represent a distinct population that is unlikely to overlap with EHBB regardless of season. JBB occupied smaller areas, re-
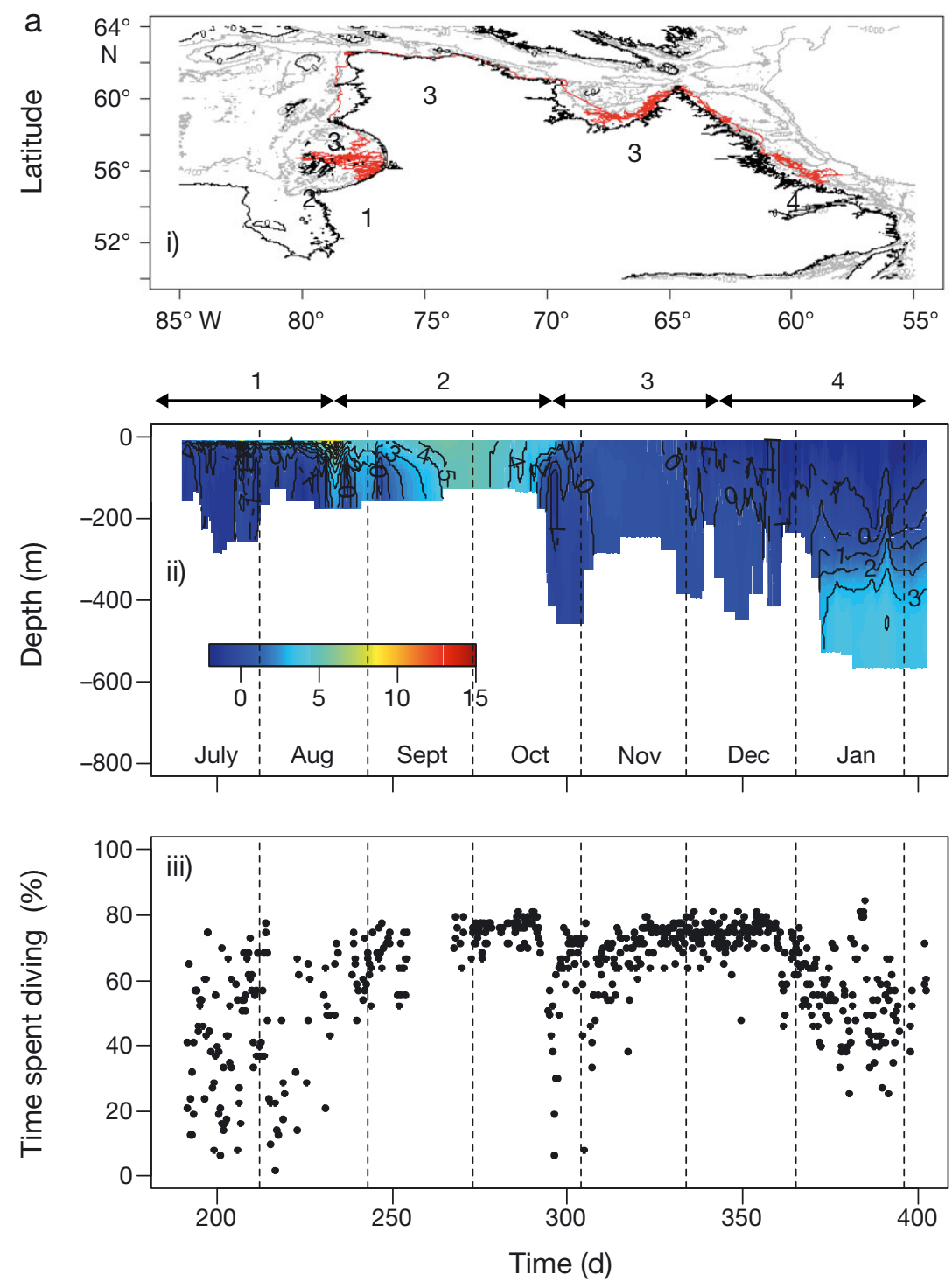

Fig. 5 (continued over page). Delphinapterus leucas. (i) Track of 1 representative individual (red line) associated with (ii) the vertical section of temperature $\left({ }^{\circ} \mathrm{C}\right.$ ) it recorded and (iii) its diving activity according to the time in (a) Eastern Hudson Bay (EHB) and (b) (next page) James Bay (JB)

mained closer to their capture site and did not undertake any significant fall/winter migration. Although some small-scale movements to the northern part of the bay were observed, the majority of JBB movements were suggestive of localized overwintering. The lack of data on diet, fish abundance and distribution in JB limits our understanding of the proximate causes of the non-migratory behaviour of JBB. However, in contrast to EHBB, JBB appear able to find favourable thermal and feeding conditions yearround. The increase in diving activity in December prior to freeze-up may reflect a change in the distri- 
b

i)
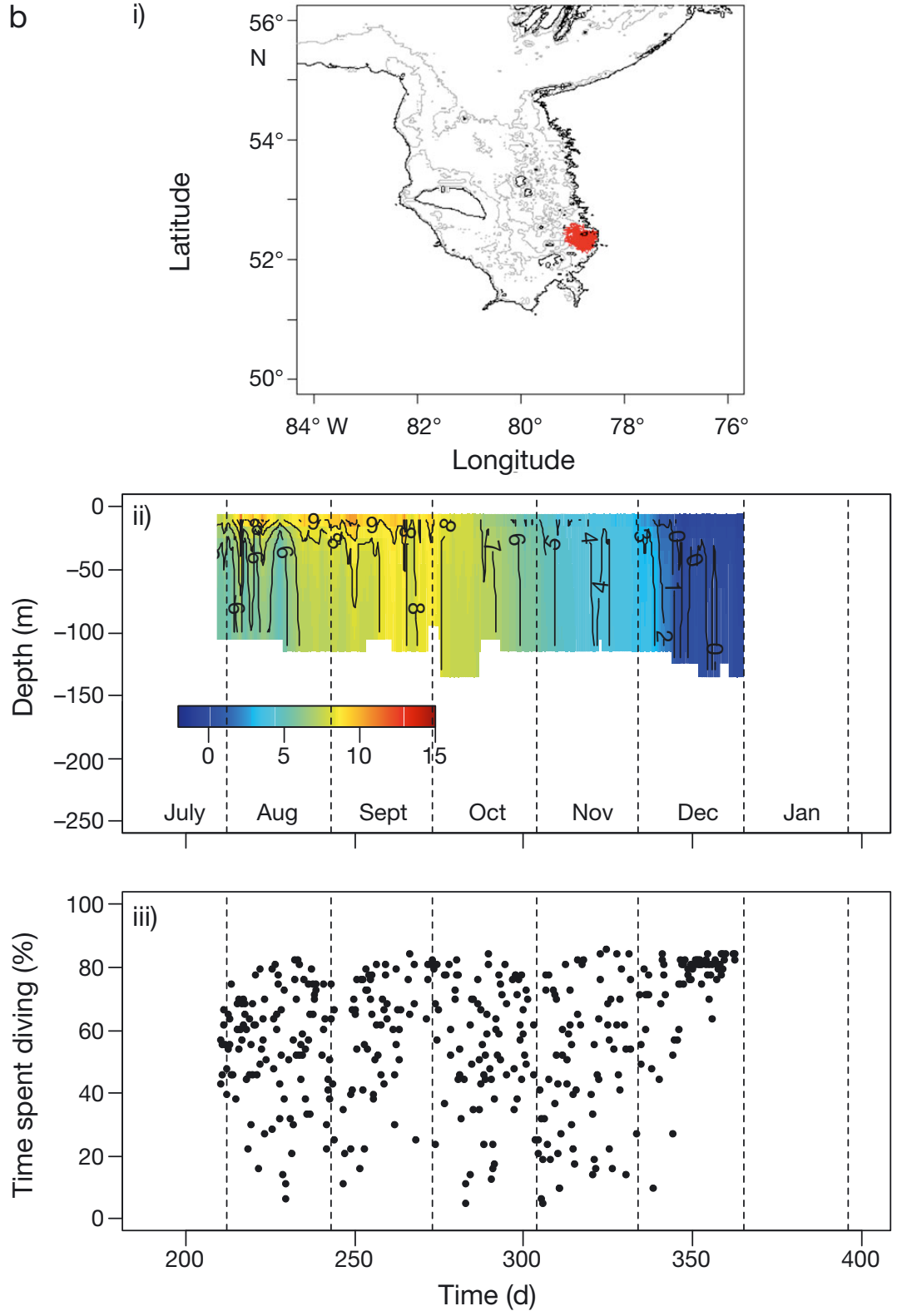

Fig. 5. (continued)

butional ecology of their main prey or a shift in diet. If sea ice represents an entrapment risk, then available JBB movement data indicate that sea-ice conditions in JB are generally conducive to successful over-wintering.

\section{Origin of differences between populations}

Predation by killer whales and ice entrapment are important causes of mortality in Arctic beluga populations (Shelden et al. 2003). Habitat selection should therefore reflect a trade-off between accumulation of energy stores and avoidance of direct mortality. Food abundance and accessibility might be affected by physical environmental conditions, including SST and sea ice. The observed differences in environmental conditions and predation risks between regions might therefore explain the observed differences in the seasonal distribution and movement patterns among beluga populations. The precise role of each factor, particularly sea ice and risks of entrapment, in shaping seasonal movement patterns of EHBB and JBB remains unclear.

Belugas generally prefer sea ice cover of $70 \%$ or less, although they also use areas with multi-year ice and ice concentrations of up to $90 \%$ (Barber et al. 2001, Asselin et al. 2011). The EHB and JB regions both begin to freeze in early December and are normally ice-covered $15 \mathrm{~d}$ later (Canadian Ice Service, www.ec.gc.ca/glacesice/). From the long time series of temperatures and sea ice concentrations illustrated in Fig. 6, we observed that SSTs during the ice-free period appreciably increased within the last $25 \mathrm{yr}$, both in EHB and in JB (Fig. 6a). Concomitantly, a decrease in winter sea ice concentration seemed to occur in $\mathrm{JB}$, while no clear tendency appeared in EHB sea ice conditions (Fig. 6b).

The evolution, distribution and ecology of belugas are greatly influenced by the dynamic nature of seasonal pack ice (Harington 2008). One could argue that the recent decrease in sea ice concentrations in JB may have provided suitable conditions for this group of animals to remain in the bay throughout the year. Although ice data were too coarse to permit detection of small bodies of open water, beluga sightings in JB suggest the occurrence of polynyas, or unconsolidated ice, and suitable and sufficient food resources in the region throughout the year. Such conditions would obviate the need for movement to winter feeding grounds (Lewis et al. 2009). In contrast, unfavourable environmental conditions and a mismatch between resource availability and demand provide likely 

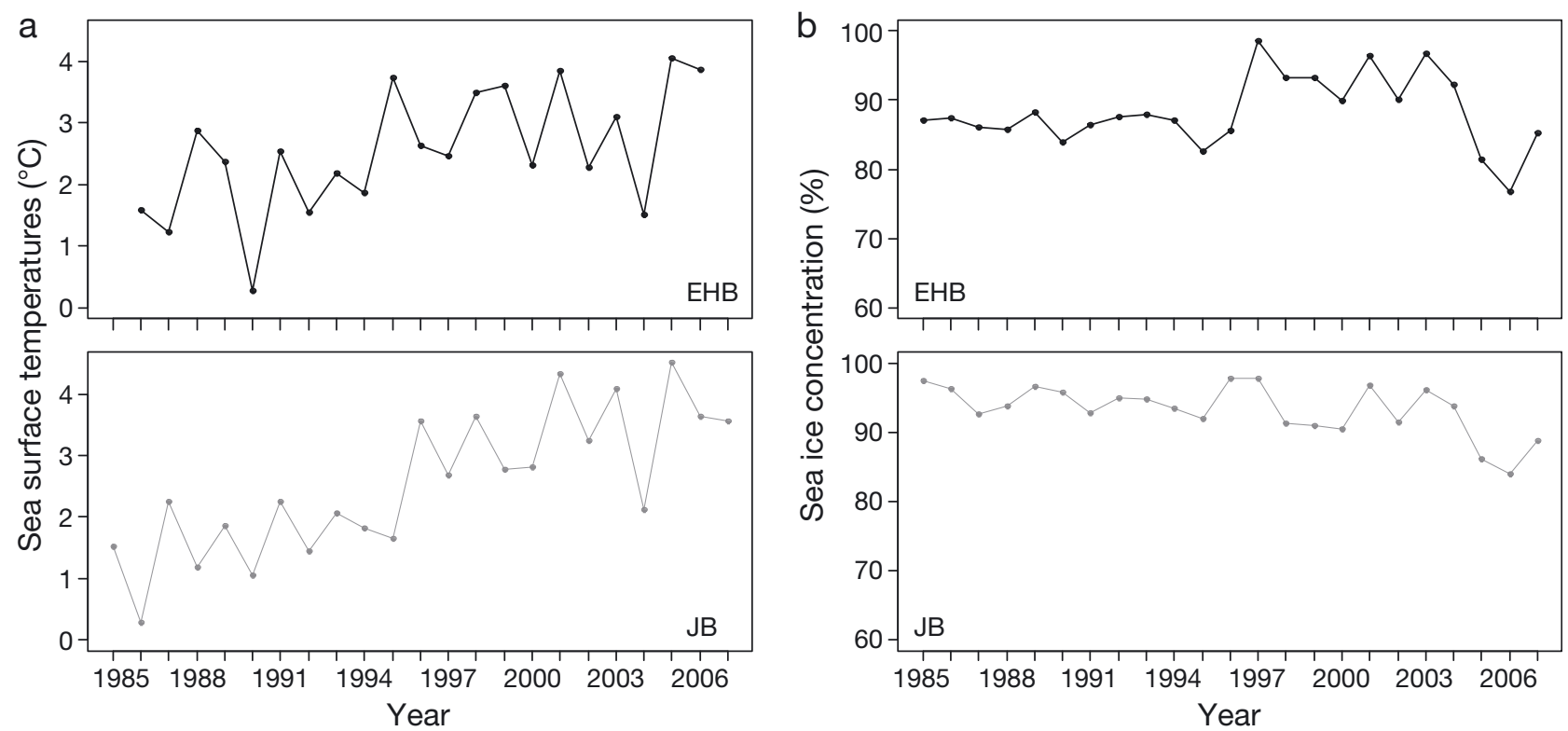

Fig. 6. Time series of (a) sea surface temperatures averaged during the ice-free period (April to November) in Eastern Hudson Bay (EHB, black) and in James Bay (JB, grey) and of (b) sea ice concentration averaged from December to March for a grid spatially limited by the maximum and minimum latitudes and longitudes reached by belugas within their summer residency areas

ecological drivers for the development of the migratory behaviour in EHBB.

The beluga is believed to be a relative generalist predator, preying upon a large number of different species, and able to occupy many different habitat types (Laidre et al. 2008). Given these characteristics, belugas might be able to exploit new ecosystems as sea ice loss opens new areas within their range (Laidre et al. 2008), as is suspected to have happened in JB. However, previous work based on early spring aerial survey observations (Jonkel 1969) and Inuit traditional ecological knowledge (Lewis et al. 2009) indicate that belugas have overwintered in JB for decades. Accordingly, environmental changes observed within the past $25 \mathrm{yr}$ may have been too recent to have appreciably impacted beluga migratory movements at coarser temporal scales.

\section{Implications for management and conservation}

By improving knowledge of complex movement patterns and periods of aggregation and mixing among beluga populations, we have clarified animal assignment to 1 stock or another. Improved assignment information is fundamental for preventing excessive removal of animals from the endangered EHB population that might have cascading effects on the local food chain and lead to marked shifts in ecosystem structure (Smetacek \& Nicol 2005). Nevertheless, results must be interpreted with caution in the absence of corroborating genetic evidence. We have also determined the spatial scale of restricted movements within each residency area, which is an important precursor to improving our understanding of critical habitat. Moreover, the physical characterization of habitat is a necessary requirement to assess current determinants of beluga distribution. For instance, a temperature around $3^{\circ} \mathrm{C}$, which might be the ecological signature of prey, seems to be targeted by EHBB for presumed foraging activity during both summer and winter periods. In contrast, JBB increased what is presumed to be foraging activity in colder waters during the freeze-up period. In the context of current Arctic climate change, such observations may be an initial point for the development of a dynamic approach that may predict future distribution of populations under plausible environmental scenarios. Although this work provides the first detailed information on the behaviour of belugas in relation to their environment in the eastern sub-Arctic, further investigation of the ecology, population interactions and genetics of the Hudson Bay beluga stock complex is needed to complement conservation policies already in place (DFO 2010) and to maintain beluga abundance and genetic diversity within the Arctic. 
Acknowledgements. We thank the people from Uniujaq and Kuujuaraapik, as well as S. Turgeon and Y. Morin, who assisted in tagging whales. Support was provided under the International Polar Year program Pan-Arctic Tagging of Beluga, ARCTICNET and the Species at Risk Program of Fisheries and Oceans Canada.

\section{LITERATURE CITED}

Asselin NC, Barber DG, Stirling I, Ferguson SH, Richard PR (2011) Beluga (Delphinapterus leucas) habitat selection in the eastern Beaufort Sea in spring, 1975-1979. Polar Biol 34:1973-1988

Barber DG, Saczuk E, Richard PR (2001) Examination of beluga-habitat relationships through the use of telemetry and a geographic information system. Arctic 54:305-316

Boily P (1995) Theoretical heat flux in water and habitat selection of phocid seals and beluga whales during the annual molt. J Theor Biol 172:235-244

Brennin R, Murray BW, Friesen MK, Maiers D, Clayton JW, White BN (1997) Population genetic structure of beluga whales (Delphinapterus leucas): mitochondrial DNA sequence variation within and among North American populations. Can J Zool 75:795-802

Buchanan FC, Friesen MK, Littlejohn RP, Clayton JW (1996) Microsatellites from the beluga whale Delphinapterus leucas. Mol Ecol 5:571-575

Caron LMJ, Smith TG (1990) Philopatry and site tenacity of belugas, Delphinapterus leucas, hunted by the Inuit at the Nastapoka estuary, eastern Hudson Bay. In: Smith TG, St. Aubin DJ, Geraci JR (eds) Advances in research on the beluga whale, Delphinapterus leucas. Can Bull Fish Aquat Sci 224:69-79

COSEWIC (Committee on the Status of Endangered Wildlife in Canada) (2004) Assessment and update status report on the beluga whale Delphinapterus leucas in Canada. Committee on the Status of Endangered Wildlife in Canada, Ottawa, ON. Available at www.cosewic.gc.ca/

DeMarch BGE, Postma LD (2003) Molecular genetic stock discrimination of belugas (Delphinapterus leucas) hunted in eastern Hudson Bay, northern Quebec, Hudson Strait, and Sanikiluaq (Belcher Islands), Canada, and comparisons to adjacent populations. Arctic 56: $111-124$

Department of Fisheries and Oceans (DFO) (2010) Nunavik and adjacent waters 2010 beluga management plan. Department of Fisheries and Oceans, Quebec Region

Doniol-Valcroze T, Hammill MO, Lesage V (2011) Information on abundance and harvest of eastern Hudson Bay beluga (Delphinapterus leucas). DFO Can Sci Advis Sec Res Doc 2010/121,

Donovan GP (1992) Report of the sub-committee on small cetaceans. Rep Int Whal Comm 42:178-234

> Ezer T, Hobbs R, Oey LY (2008) On the movement of beluga whales in Cook Inlet, Alaska: simulations of tidal and environmental impacts using a hydrodynamic inundation model. Oceanography 21:186-195

Fauchald P, Tveraa T (2003) Using first-passage time in the analysis of area restricted search and habitat selection. Ecology 84:282-288

- Harington CR (2008) The evolution of Arctic marine mammals. Ecol Appl 18(Suppl):S23-S40

Hessen DO, Carroll J, Kjeldstad B, Korosovd AA, Pettersson LH, Pozdnyakov D, Sørensen K (2010) Input of organic carbon as determinant of nutrient fluxes, light climate and productivity in the $\mathrm{Ob}$ and Yenisey estuaries. Estuar Coast Shelf Sci 88:53-62

Higdon JW, Ferguson SH (2009) Loss of Arctic sea ice causing punctuated change in sightings of killer whales (Orcinus orca) over the past century. Ecol Appl 19: 1365-1375

Hobbs R, Shelden K, Rugh D, Norman S (2008) Status review and extinction assessment of Cook Inlet belugas (Delphinapterus leucas). AFSC Proc Rep 2008-02. Alaska Fisheries Science Center, National Marine Fisheries Service, NOAA, Seattle, WA

Jonkel CJ (1969) White whales wintering in James Bay. J Fish Res Board Can 26:2205-2207

Kelley TC, Loseto LL, Stewart REA, Yurkowski M, Ferguson SH (2010) Importance of eating capelin: unique dietary habits of Hudson Bay beluga. In: Fergusson SH, Loseto LL, Mallory ML (eds) A little less Arctic: top predators in the world's largest northern inland sea, Hudson Bay. Springer, Dordrecht, p 53-70

Kingsley MCS, Gosselin S, Sleno GA (2001) Movements and dive behavior of belugas in northern Quebec. Arctic 54: 262-275

Laidre KL, Stirling I, Lowry LF, Wiig $\varnothing$, Heide-Jørgensen MP, Ferguson SH (2008) Quantifying the sensitivity of Arctic marine mammals to climate-induced habitat change. Ecol Appl 18(Suppl):S97-S125

Lesage V, Kingsley MCS (1998) Updated status of the St. Lawrence River population of the beluga, Delphinapterus leucas. Can Field Nat 112:98-113

Lewis A, Hammill M, Power M, Doidge D, Lesage V (2009) Movement and aggregation of Eastern Hudson Bay beluga whales (Delphinapterus leucas): a comparison of patterns found through satellite telemetry and Nunavik traditional ecological knowledge. Arctic 62:13-24

- Maslanik JA, Serreze MC, Barry RG (1996) Recent decreases in Arctic summer ice cover and linkages to atmospheric circulation anomalies. Geophys Res Lett 23: 1677-1680

Moore SE, Shelden KEW, Litzky LK, Mahoney BA, Rugh DJ (2000) Beluga whale, Delphinapterus leucas, habitat associations in Cook Inlet, Alaska. Mar Fish Rev 62: $60-80$

Petersen SD, Hainstock M, Wilson PJ (2010) Population genetics of Hudson Bay marine mammals: current knowledge and future risks. In: Ferguson SH, Loseto LL, Mallory ML (eds) A little less Arctic: top predators in the world's largest northern inland sea, Hudson Bay. Springer, Dordrecht, p 237-265

Piepenburg D (2005) Recent research on Arctic benthos: common notions need to be revised. Polar Biol 28: 733-755

Reeves RR (2000) The value of sanctuaries, parks, and reserves (protected areas) as tools for conserving marine mammals. Final Report to the Marine Mammal Commission, contract number T74465385. Marine Mammal Commission, Bethesda, MD

Reeves RR, Mitchell E (1987) History of the white whale (Delphinapterus leucas) exploitation in eastern Hudson Bay and James Bay. Canadian Special Publication of Fisheries and Aquatic Sciences 95

Richard PR (1991) Status of the belugas, Delphinapterus leucas, of Southeast Baffin Island, Northwest Territories. Can Field Nat 105:206-214

Richard PR, Orr JR, Barber DG (1990) The distribution and 
abundance of belugas, Delphinapterus leucas, in eastern Canadian subarctic waters: a review and update. In: Smith TG, St. Aubin DJ, Geraci JR (eds) Advances in research on the beluga whale, Delphinapterus leucas. Can Bull Fish Aquat Sci 224:23-38

Richard PR, Martin AR, Orr JR (1997) Study of summer and fall movements and dive behavior of Beaufort Sea belugas, using satellite telemetry: 1992- 1995. Environ Studies Res Funds Rep No. 134

Richard PR, Heide-Jorgensen MP, St. Aubin D (1998) Fall movements of belugas (Delphinapterus leucas) with satellite-linked transmitters in Lancaster Sound, Jones Sound, and Northern Baffin Bay. Arctic 51:5-16

Richard PR, Martin AR, Orr JR (2001) Summer and autumn movements of belugas of the eastern Beaufort Sea stock. Arctic 54:223-236

Ropert-Coudert Y, Wilson RP (2005) Trends and perspectives in animal-attached remote-sensing. Front Ecol Environ 3:437-444

Saucier FJ, Senneville S, Prinsenberg S, Roy F and others (2004) Modelling the sea ice-ocean seasonal cycle in Hudson Bay, Foxe Basin and Hudson Strait, Canada. Clim Dyn 23:303-326

Shelden KEW, Rugh DJ, Mahoney BA, Dahlheim ME (2003) Killer whale predation on belugas in Cook Inlet, Alaska: implications for a depleted population. Mar Mamm Sci 19:529-544

Smetacek V, Nicol S (2005) Polar ocean ecosystems in a changing world. Nature 437:362-368

Editorial responsibility: Sascha Hooker,

St. Andrews, UK
St. Aubin DJ, Smith TG, Geraci JR (1990) Seasonal epidermal molt in beluga whales, Delphinapterus leucas. Can J Zool 68:359-367

Stewart BE, Stewart REA (1989) Delphinapterus leucas. Mamm Species 336:1-8

Stirling I, Lunn NJ, Iacozza J, Elliott C, Obbard M (2004) Polar bear distribution and abundance on the southwestern Hudson Bay coast during open water season, in relation to population trends and annual ice patterns. Arctic $57: 15-26$

Svendsen H, Beszczynska-Møller A, Hagen JO, Lefauconnier B and others (2002) The physical environment of Kongsfjorden-Krossfjorden, an Arctic fjord system in Svalbard. Polar Res 21:133-166

Tremblay Y, Robinson PW, Costa DP (2009) A parsimonious approach to modeling animal movement data. PLoS ONE 4:e4711

Walsh JE (2008) Climate of the Arctic marine environment. Ecol Appl 18:S3-S22

Walther GR, Post E, Convery P, Menzel A and others (2002) Ecological responses to recent climate change. Nature 416:389-395

> Watts PD, Draper BA, Henrico J (1991) Preferential use of warm water habitat by adult beluga whales. J Therm Biol 16:57-60

Welch HE, Crawford RE, Hop H (1993) Occurrence of arctic cod (Boreogadus saida) schools and their vulnerability to predation in the Canadian High Arctic. Arctic 46: 331-339

Submitted: May 24, 2011; Accepted: January 18, 2012 Proofs received from author(s): February 27, 2012 